\title{
The Quality Management of Higher Education on the Job Performance of Lecturers Basis
}

\author{
Srie Faizah Lisnasari \\ Education Dept of Universitas Quality Medan Indonesia
}

\begin{abstract}
The quality management of higher education depends on human resources quality. The objective of this research was concerning with the Quality management of Indonesian higher education that involved the effect of self-efficacy, rewards and work motivation on job performance. This research was conducted in Medan Municipal by using a survey methods with path analysis applied in testing hypothesis. It involved 79 head of departments in higher education as respondents who were selected by proportional random sampling. This research findings were as follows: (1) There was a direct effect of self-efficacy on job performance, (2) There was direct effect of rewards on job performance, (3) There was a direct effect of work motivation on job performance, (4) There was direct effect of self-efficacy on work motivation, (5) There was direct effect of rewards on work motivation. Therefore, job performance could be improving by rising the self-efficacy, rewards and work motivation.
\end{abstract}

Keywords: Self-efficacy, Rewards, Work Motivation and Job Performance.

\section{BACKGROUND}

Quality management of university today is challenged by the emergence of a new paradigm in determining quality. The management of higher education is measured through results and performance in sustainable quality (Crespo et al, 2017). Along with this paradigm there are changes in the management pattern of Higher Education (Ferrer-Balas, 2008). The implementation of performance management is getting a lot of attention. Human resource management (HRM) is considered inadequate in meeting the need for guidance on quality human resources, so that began to develop the pattern of human resource performance management. The challenges faced in HRM performance management are concerning with the performance management model relevant to individual needs and job characteristics. Therefore, it is needed the performance assessments both empirical and theoretical.

Job performance is related to the work productivity, work result and work performance. Academic performance is a product of personal determination, cognitive development and motivation as well as several other correlates (Kapinga \& Amani, 2016). The focus in managing universities is to improve their performance, but at the same time the autonomy of institutions is decreasing and the power of central institutions is increasing (James in Türk, 2016). An academic assessment of concepts and performance models can be used to explain and predict this new phenomenon. In performance management on the characteristics of a particular institution shows the way of handling human resources in which self-efficacy, motivation and rewards led to job performances.

The problem faced in performance management is not only in determining the performance indicators; anyhow, furthermore it is in determining the internal and external factors that affect the job performance. Inuwa (2016) reveals that at present performance can be built through the development of different and sustainable values that is by increasing intangible 
assets, such as human resources, technology and organizational resources. This is based on the understanding that intangible assets are able to generate added value by $75 \%$, while the average tangible asset is only able to present less than 25\%. Dehaghi \& Rouhani (2014) found that performance is influenced by attitudes, beliefs and individual abilities. In contrast, Vosloban (2012) showed that career and self-efficacy affect the individual performance.

There is the relationship between work match and performance found Wahab (2016), Differences of variables that affect performance are not only found from the results of research, found also in the existing models of performance theory. Nabi et al (2017) suggested that the performance was influenced by motivation, while the process of emergence of motivation is influenced by individual factors and by the work factor itself. In contrast to Koopmans et al (2011) suggesting that individual performance is influenced by individual business and individual performance, then individual performance affects rewards from the organization and further affects individual goals. So in this case, the apparent difference between the two theories is the effect of rewards on performance.

The next exploration results on performance models show that Mensah \& Tawiah (2016) suggests different models from previous models. If in the previous theory there are differences in variables that directly affect the performance, especially on the variables of motivation and variables derived from individuals, the motivation affecting business and business that affect the performance in addition to the ability and environmental variables.

Differences of variables found in the four models have been raised raises the question, why there is a difference of expert opinion on the variables that affect the performance? Then, why there are variables directly affect the performance while by other experts put forward indirect effect. Thus, these theories need to be clarified again by exploring other theories about performance. In this way is expected to be obtained a more comprehensive understanding of the variables that affect performance.

At Goal Setting theory, Teo \& Low (2016) suggest a direct influence together goal commitment and self-efficacy where in previous models this is not found. Both models have the same view that self-efficacy directly affects performance, but this theory is different in determining the variables that come from individual self. In the Goal Setting Theory, self-efficacy and individual commitment influence simultaneously on performance (Lunenburg, 2011).

In the next explanation Kinicky (2006) found that effort directly affect the performance, while the performance of reciprocal relationship with reward and positive reinforcement, then performance also related reciprocity with feedback. In this case, the reward and positive reinforcement was directly influenced the effort. Sinawi et al (2015) in the model of motivation suggests that performance is influenced by effort and ability. This view is in line with Muda (2014), ability has a significant impact to the performance.

The results of the exploration of several performance models presented by these experts show that various variables are found to affect performance either directly or indirectly. The variables affecting performance are motivation, effort, skill and ability, perception role, environment, organizational support, self-efficacy, goal commitment, individual sourced factors, job knowledge, traits, emotion, mood, belief and value, environment, job design, reward and reinforcement, social norms, supervision and organizational culture and organizational goals. 
If the results of the research and the views of these experts are used to explain the performance of human resources in Higher Education then this becomes very complicated, given the number of variables that affect the performance and variations in the relationship between these variables. Therefore we need a certain performance model that can be used to explain, understand and predict the performance of human resources in Higher Education. The results of the analysis on the characteristics of human resources in universities, especially the head of the study program becoming technical management found that the competencies underlying their duties and responsibilities are related to conceptual skills, people skills and technical skills. Based on these characteristics, it is assumed that the variables related to internal and external conditions influence the performance of the department chairman. But to test it theoretically and empirically required a particular model, so in this discussion the basic model that is thought to be relevant to build this new performance model is a model of A Job Performance Model of Motivation proposed by Kinicki and Kreitner (2006). So the variables used to build new models are self-efficacy, rewards and work motivation. Thus in this discussion will be tested how the influence of self-efficacy, rewards and motivation to performance. This performance model will be tested empirically at Islamic Higher Education in Medan City.

Based on problem restrictions, the research problem is formulated as follows: (1) Does selfefficacy have direct effect on performance? (2) Does rewards have a direct effect on performance? (3) Does work motivation have a direct effect on performance? (4) Does selfefficacy have direct effect on work motivation? (5) Does rewards have direct effect on work motivation?

\section{Performance}

Performance can be interpreted as the work that can be achieved individual or a group of individuals within an organization. These results are in accordance with the authority and responsibility of each individual in an effort to achieve organizational goals. Some experts argue that performance is performance work. Performance as a totality of behavior put forward by Khan et al (2011). According to him this is related to the work displayed by individuals in accordance with organizational expectations Different definitions put forward Colquitt (2009) in the integrative model of organizational behavior. According to Colquitt, performance is an individual behavior based on a certain value in contributing to the achievement of organizational goals. He added that performance has three dimensions which he calls "Task Performance, Citizenship Behavior and Counterproductive Behavior". Performance is as a rational performance. It defines rational performance as individual satisfaction in achieving goals that fit the needs of the organization. Motivation and self-efficacy in the reward process theory proposed by Gibson obtained the understanding that the actual improvement of individual performance is highly dependent on the results of his evaluation of the rewards obtained from the performance.

Robbin in Expectancy Theory that one's efforts affect performance. So if you want to improve the performance then can be pursued through the improvement of the individual business. While the competencies required by a chairman of the study program according to Tucker (in Taylor, 2016) are as follows: (1) display in implementing good interpersonal relationships; (2) the behavior of identifying and solving problems in a way acceptable to the members of the study program; (3) behaviors in adjusting the leadership style to different situations, (4) behavior in establishing the objectives of the study program in order to move the study program toward the achievement of the objectives, (5) the behavior in finding the optimum strength as the head of study program, and motivating the program study members to develop the purpose of the study program, (6) active participation in the profession and respect of the 
profession of his colleagues. If the roles, duties, responsibilities and competencies of the head of the study program are related to the expert opinion and performance theories already proposed in this discussion such as Whitmore, Minner, Griffin, and Colquit can be synthesized that the performance (job performance) is the display of individual behavior in running tasks and responsibilities to achieve goals. So it can be argued that the performance of the head of the study program is the behavior it shows in carrying out the duties and responsibilities to achieve the goals. In this case the behavior is related to the competence of the chairman of the study program are: (1) the appearance in carrying out good interpersonal relationships; (2) the behavior of identifying and solving problems in a way acceptable to the members of the study program; (3) behaviors in adjusting the leadership style to different situations, (4) behavior in establishing the objectives of the study program in order to move the study program toward the achievement of the objectives, (5) the behavior in finding the optimum strength as the head of study program, and motivating the program study members to develop the purpose of the study program, (6) active participation in the profession and respect of the profession of his colleagues.

\section{Self-Efficacy}

Self-efficacy is a person's belief in his ability to accomplish a particular task. Greenberg (2008) says that self-efficacy is a person's belief in his ability to accomplish tasks to achieve his goals. This opinion is in line with the opinion of Yadak (2017) who says that self-efficacy is an individual's belief in his ability to mobilize his motivation, the source of his knowledge and the way he acts so that he succeeds in performing specific tasks according to the prescribed context. Kinicky pointed out that self-efficacy is a belief about the possibility of success in completing specific tasks. Similarly, the opinion of Jennifer (2009) that self-efficacy is a person's belief in his ability to perform specific behaviors with success. Another more specific definition is expressed by Türkoğlu et al (2017) as follow; self-efficacy is one's belief in its ability to perform successfully. Self-efficacy directs one's behavior in work. Although a person is offered an attractive reward if successful completes a particular task, the person tends not to accept it if his efficacy is not positive. Conversely, if the individual's individual self-efficacy tends to set goals that are difficult to achieve because he is convinced of his ability to achieve goals with good treatment of those who have tried to achieve them so that their long-term work ability is maintained.

Self-efficacy affects motivation, either when individuals are rewarded or when individuals do so on their own, the higher the self-efficacy the greater the motivation and performance. Selfefficacy is a person's belief in his ability to perform a specific task and in some ways has similarities to self-esteem and locus of control. Sharma \& Singh (2017) defines self-efficacy as an assessment of one's ability to complete a certain level of work. Furthermore, according to Bandura self-efficacy has a significant influence on the work, skills and knowledge it possesses. Foster et al (2015) state that self-efficacy is likely to change according to the task to be selfmanaged and is subject to change. It has therefore become the target of many self-management interventions. Self-efficacy is not a general trait and therefore a person cannot be described as having high self-efficacy or low self-efficacy in all situations. Rather, individuals have beliefs about their ability to carry out tasks and these will vary according to the context and the nature of the task. For example, someone may have high self-efficacy in the workplace but low selfefficacy in relation to exercise. Going further, someone who reports high self-efficacy in the workplace may have quite different self-efficacy beliefs when work-related self-efficacy is examined in more detail e.g. high self-efficacy for managing a team but low self-efficacy for delivering a pitch to an audience. Thus it can be argued that the high self-efficacy in a person can be observed from the belief in his ability to overcome the challenges faced in completing the task. Self-efficacy is a person's belief in his ability to exert his motivation, the source of his 
knowledge and the way he acts so as to succeed in performing specific tasks in accordance with predetermined goals and when linked with self-efficacy indicators.

\section{Rewards}

Rewards are something that is expected to be accepted as desired. Rewards can also be defined as the rewards that a worker will receive in accordance with the performance he or she gives to the organization. Reward as something desirable, is a positive reinforcement to strengthen and improve work behavior with the desired consequences. Rewards have the power to influence workers' behavior called reward power. According to Kinicki, rewards can deliver the desired results. This is in line with the opinion of Lawler (in Ajmal et al, 2015), which classifies rewards on intrinsic and extrinsic types. The intrinsic types are: psychic rewards and self-acknowledgment. Extrinsic types are: financial, material, or social reward. Individualgenerated performance will receive a variety of intrinsic and extrinsic rewards. Intrinsic rewards are rewards that are valued from within. An example of intrinsic rewards is the individual's sense of personal competence as a result of doing a good job, personal feelings of achievement, responsibility and personal autonomy and a sense of personal growth and development.

Extrinsic rewards have the potential to exert a powerful influence on individual behavior within the organization. These rewards are often used by organizations in an attempt to influence employee behavior and performance. Included in extrinsic rewards is the recognition and praise of superiors, promotions, financial benefits and social benefits such as the opportunity to befriend and meet new people. One form of reward is satisfaction. In this respect Lawler (in Ajmal et al, 2015) concludes five conclusions about the relationship between individual satisfaction and the reward for this behavioral study: (1). Satisfaction with rewards are two things that affect each other, the expectations and reality of the rewards received will affect satisfaction, (2). The individual's contented feelings are influenced by comparing the inputs given and those given by others with the acceptance of their respective rewards; (3). Satisfaction is influenced by the existence of intrinsic reward factors and extrinsic rewards. Intrinsic rewards are influenced from within themselves, they attribute to their performance, as an example of a feeling of achievement and success; (4). People differ on the rewards they want and this is relative to the acceptance of the rewards they receive. In fact, the preferred rewards vary according to career differences, age and varied situations, (5). Some extrinsic rewards are more satisfying because they dominate other rewards. This opinion is supported by Bergström \& Martínez (2016) that rewards can be grouped on financial and non-financial. Other types of rewards, which are based on the reward pyramid: first on base pay, performance, and profit sharing. These three types are mutually supportive. Base pay is the reward received in the form of adjustments in recognition of skills upgrades, cost-of living pay adjustments, seniority increases, rewards due to overtime work , rewards for holidays, pensions, unemployed compensation, and other non-economic benefits such as giving holidays for hours / days of work or additional wages in lieu of unpaid hours of work. Performance pays are rewarded in the form of grant incentives and adjustment of incentives on the basis of seniority. Profit rewards such as annual bonuses at the end of the fiscal year on the basis of organizational benefits.

In line with the above explanation, according to Slocum (2009), there are four popular rewards programs that influence performance: gain-sharing, profit sharing, skill-based pay and flexible benefit programs. Other types of rewards, namely: (1) Material rewards; (2) Social rewards, (3) Task rewards, and (4) Personal Rewards. The reward materials include: financial payment range (salary, bonus, benefit), work safety, financial welfare. Social rewards include: rewards by managers and groups of workers, promotions, awards from customers, respect and 
friendship from co-workers. Task rewards include: an opportunity to gain responsibility and authority, opportunities for achievement improvement, opportunities to improve more valuable work. Personal rewards include: opportunities to learn, opportunities for self-worth / status enhancement, career development. If connected with the function, role and responsibility of the Program study Leader with the reward theory proposed by Luthans, Jennifer, Kinicki and Gibson it can be synthesized that rewards are the rewards individuals expect to gain from their work either from external factors such as income, promotion, health services or in the form of feelings of pleasure for the successful completion of the task, a sense of meaning for others and satisfaction of his work performance.

\section{Work Motivation}

Motivation can be interpreted as a person's strength or energy that can lead to the level of persistence and enthusiasm in carrying out an activity, either from within the individual (intrinsic motivation) or from outside the individual (extrinsic motivation). Work motivation is a series of forces from within and outside that cause workers to choose the path of action and invite to certain behaviors. Work motivation is a complex combination of psychological forces that exists in every person, and workers' pay great attention to three elements: a) the direction and focus of behavior (positive factors such as: reliable, creative, helpful, timely; non-functioning factors such as: slowness, absenteeism / absenteeism, withdrawal from society and low performance). b) The level of effort (having a commitment to good work quality, contrary to doing work just at least). c) Endurance of behavior (repeatedly maintaining an opposite endeavor by pausing). This is in line with the opinion of Greenberg (2008) who said that motivation is a series of processes that move, regulate and maintain human behavior toward the achievement of goals. Three things that become key components of motivation are: 1). A person's high performance does not mean that his motivation is too high, Motivation is just one of several factors that determine performance; 2). someone may have different motivations at the same time; 3). someone is motivated more than just money. Money is not a very powerful thing to motivate workers but the prospect of performance is an interesting and challenging thing; getting wages is the third after a challenging project and team spirit. This opinion is also supported by Colquit (2009) which defines motivation as a series of vigorous forces coming from outside and within the worker, starting a workrelationship business, and determining the direction (intensity (what are you going to do right now?) how hard are you going to work on it?) and perseverance (persistence) (how long are you going to work on it?). This opinion is in line with Kinicki's (2006) opinion which explains that motivation describes the psychological process that moves the direction and perseverance of voluntary action to its real purpose. In line with that, Mitchell and Daniels in Kinicky and Robert in A Job Performance Model of Motivation explained that motivated behaviors are influenced by individual inputs and job contexts. Motivation combines the power within a person that influences the purpose, incentives and persistence of behavior voluntarily. The same thing is presented by Jennifer (2009) that work motivation is defined as a psychological force within a person that determines the direction of the person's behavior in the organization, level of effort and resilience against obstacles. There are three key elements of work motivation namely the direction of behavior, business level and level of persistence (persistence). The direction of behavior is what behavior is chosen in an organization. The level of effort is one's effort to improve the chosen behavior and the level of endurance is the extent to which a person can survive to face problems, obstacles and challenges. Intrinsically motivated work behaviors are self-directed behaviors, whereas extrinsic motivation is a behavior established to obtain material or social rewards or to avoid punishment. In line with Maslow's theory, Herzberg in Greenberg (2008) developed a "Model Two Factor" motivation, namely motivational factors and hygiene factors or "maintenance". He believes that an individual's relationship to work is fundamental and one's attitude toward work is crucial to 
success or failure. According to Herzberg, motivational factors are anything that pushes for achievement that is intrinsic, while hygiene or maintenance factors are factors that are extrinsic, which means sourced from outside the self that helped determine one's behavior in one's life. Things that are classified as a motivational factor (intrinsic), among others, are a person's job, success achieved, opportunities to grow, career advancement and recognition of others. While hygiene or maintenance factors (extrinsic) include, among other things, the status of a person in the organization, the relationship of an individual with his / her superior, a person's relationship with his / her colleagues, organizational policies, organizational systems in the organization, working conditions and applicable reward system.

If it is related to the function, role and responsibility of the Program study Chairman with the motivation theory of work proposed by Newstrom, Greenberg, Colquit and Kinicki which states that work motivation is the power of individuals in completing their duties and responsibilities, also with indicators of work motivation according to Newstrom namely: behavior, level of effort and endurance (endurance) in performing tasks, then conceptually, work motivation can be synthesized as an individual strength in completing task and responsibility both in determining the direction and behavior, level of effort and endurance in carrying out tasks

\section{Self-efficacy on Performance}

Performance (job performance) is a behavior shown by individuals in work in accordance with the expectations of the organization. Job behavior is in the form of activity in carrying out its duties and responsibilities. The success of the individual in carrying out his activities is derived from factors from within himself and from outside himself. Factors from within him such as: motivation, intellectual ability, personality, the concept of himself while from outside himself such as work conditions, work environment, social environment. An essential factor associated with that person is the self-concept of how one describes the ideal self he is hoping for with a picture of reality about himself. The forms of self-image include self-confidence, self-esteem and self-esteem. The picture is directly related to the success of individuals in completing the work of self-efficacy into a determining factor in individual performance. When the individual has high self-efficacy, then the person will always feel confident able to perform their duties properly and confident of its ability to face various challenges or obstacles in achieving its work goals. A very strong belief in this ability will encourage individuals to gain achievement in their work. These successes will illustrate the overall performance of a person in his work. Therefore, in improving the performance of individuals need to have high self-efficacy to push it to achieve optimal performance. A person's belief in his ability is a determinant of one's performance level. Without good self-efficacy, people tend to fail to demonstrate their optimal performance even though they have a good knowledge of what needs to be done and the skills required to complete the job. Individuals can fail to perform tasks optimally because they doubt their ability to complete the task. Based on this, it can be argued that if individual selfefficacy is high, then performance will also be high.

\section{Performance Rewards}

Rewards are rewards that individuals will receive for their contribution to the organization. The reward system generally organizes rewards according to individual performance within the organization. Thus, individuals will be rewarded on the basis of their performance within the organization. For an individual the size of the reward depends heavily on his judgment on the reward received so that a person who is rewarded in accordance with his or her wish will be pleased and motivated to repeat his or her job to earn the reward. Conversely a person who judges the rewards he receives does not match his expectations, will reduce his efforts, and tend not to contribute as expected. An overview of individual work results shows its 
performance. Therefore, the better a person's assessment of the rewards he receives, the more driven the individual is to perform better. Thus if the individual's assessment of the award received for his performance is good, then the individual tends to improve his performance.

\section{Work Motivation on Performance}

Motivation work can be interpreted as a power (energy) a person in achieving a goal of work. A person who has a strong working motivation will direct all his strength to achieve goals and have the fighting power in overcoming obstacles to achieve his goals and have the resolve to stay focused on the goals to be achieved. Individuals, who have high work motivation, tend to have good performance. The stronger the motivation of individual work, the greater the energy to achieve the goals will affect the achievement of performance.

\section{Self-Efficacy on Work Motivation}

Self-efficacy is an individual's belief in his ability to exert his motivation, the source of his knowledge and the way he acts so as to succeed in performing tasks. Self-efficacy affects motivation, either when individuals are rewarded or when individuals do so on their own. Confidence in one's own ability affects personal motivation. Conversely, the higher the belief in his own ability, the more determined his determination to complete the task well. Individuals who have high self-efficacy, will always feel confident to carry out their duties properly and confident of its ability to face various challenges or obstacles in achieving its work goals. A very strong belief in this ability will motivate the individual to gain achievement in his work, the higher the self-efficacy the greater the motivation and performance.

\section{Rewards for Work Motivation}

Rewards are rewards expected to be received by individuals for their contribution to the organization in terms of both intrinsic and extrinsic rewards. Extrinsic rewards can be salary, promotion, whereas intrinsic rewards can be psychological rewards. When an individual judges the rewards he receives in accordance with what he expects, then the individual will be motivated to repeat his work in order to recover the rewards he has received before. Expectations for increased benefits received, will increase work motivation.

\section{Research Hypotheses}

The research hypothesis is proposed as follows:

1. Self-efficacy has a direct positive effect on Performance

2. Rewards have a positive direct effect on Performance.

3. Work Motivation has a direct positive effect on Performance.

4. Self-efficacy has a direct positive effect on Work Motivation

5. Rewards have a positive direct effect on Work Motivation.

\section{RESEARCH METHODOLOGY}

The research was conducted in Medan on the study program which is located at Universitas Islam Sumatera Utara (UISU), Al-Washliyah University, Muslim Nusantara University (UMN), and University of Muhammadiyah Sumatera Utara (UMSU). Before the research is conducted, firstly it was done permission research, test instrument, validation and perfection of the instrument. This research was conducted by survey method with causal technique while to analyze the influence of one variable with another variable used path analysis. The number of respondents in this study was 79 heads of study proportionally taken randomly from the population of 106. 


\section{Research Result and Discussion}

Before performing the test, first it was done the test requirements analysis of the Test Normality and Test Linearity.

\section{Normality test}

Testing normality of regression estimation error was done by using Lilliefors method, i.e nonparametric normality test. To determine the normality of the population based on the sample data, then tested the proposed statistical hypothesis, namely: H0: The standard error regression equation estimates are not normally distributed H1: The standard error regression equation estimates are normally distributed

Through the Lilliefors (L) test, the acceptance or absence of the null hypothesis is determined by the comparison result between Lhit and Ltab for a level of significance $\alpha=0,05$. The value of Ltab $(\alpha=0,05)=0,886 / \sqrt{ } n$, where $n=$ the number of sample. Therefore, Ltab $(\alpha=0,05)=$ $0,886 / \sqrt{ } 27=0,100$. The criterion needed to test the null hypothesis is:

HO : rejected if Lhit $\leq$ Ltab

HO : accepted if Lhit > L tab

The summary of the results of hypothesis testing of data normality are as follows:

Table 1. Summary Data Test Result Data Normality

\begin{tabular}{|l|l|c|c|c|l|}
\hline No & \multicolumn{1}{|c|}{ Variable data } & & Lhit & Ltab & Results \\
\hline 1 & $\begin{array}{l}\text { Score performance against } \\
\text { self-efficacy }\end{array}$ & $\mathrm{X} 4, \mathrm{X} 1$ & 0,044 & 0,100 & $\begin{array}{l}\text { Normal } \\
\text { Distribution }\end{array}$ \\
\hline 2 & $\begin{array}{l}\text { Performance score on } \\
\text { rewards }\end{array}$ & $\mathrm{X} 4, \mathrm{X} 2$ & 0,066 & 0,100 & $\begin{array}{l}\text { Normal } \\
\text { Distribution }\end{array}$ \\
\hline 3 & $\begin{array}{l}\text { Performance score on work } \\
\text { motivation }\end{array}$ & $\mathrm{X} 4, \mathrm{X} 3$ & 0,042 & 0,100 & $\begin{array}{l}\text { Normal } \\
\text { Distribution }\end{array}$ \\
\hline 4 & $\begin{array}{l}\text { Job motivation score on } \\
\text { rewards }\end{array}$ & $\mathrm{X} 3, \mathrm{X} 2$ & 0,037 & 0,100 & $\begin{array}{l}\text { Normal } \\
\text { Distribution }\end{array}$ \\
\hline 5 & $\begin{array}{l}\text { Work motivation score on } \\
\text { self-efficacy }\end{array}$ & $\mathrm{X} 3, \mathrm{X} 1$ & 0,084 & 0,100 & $\begin{array}{l}\text { Normal } \\
\text { Distribution }\end{array}$ \\
\hline
\end{tabular}

Based on the above table it is known that the variable data in the form of self-efficacy score (X1), reward (X2), work motivation (X3) on performance (X4) and data variable of reward data (X2) on work motivation (X3), and self-efficacy data (X1) to work motivation (X3) is qualified.

\section{Test of Linearity and Significance of Regression Equation}

Linearity test is done to see the linear between exogan variable and endogenous variable through regression equation $\mathrm{Xi}=\mathrm{a}+\mathrm{bXi}$. There are five simple regression equations tested for linearity and significance, as seen in the following summary:

Table 2. Summary of simple regression equation form

\begin{tabular}{|l|l|l|l|}
\hline Type of Equation & Permanent & $\begin{array}{l}\text { Regression Direction } \\
\text { Coefficients }\end{array}$ & $\begin{array}{l}\text { Form of Regression } \\
\text { Equation }\end{array}$ \\
\hline $\mathrm{X} 41: \mathrm{X} 4=\mathrm{a}+\mathrm{bX} 1$ & $\mathrm{a}=72,091$ & $\mathrm{~b}=0,391$ & $\mathrm{X} 4=72,091+0,391 \mathrm{X} 1$ \\
\hline $\mathrm{X} 42: \mathrm{X} 4=\mathrm{a}+\mathrm{bX} 2$ & $\mathrm{a}=39,129$ & $\mathrm{~b}=0,870$ & $\mathrm{X} 4=39,129+0,870 \mathrm{X} 2$ \\
\hline $\mathrm{X} 43: \mathrm{X} 4=\mathrm{a}+\mathrm{bX} 3$ & $\mathrm{a}=63,583$ & $\mathrm{~b}=0,480$ & $\mathrm{X} 4=63,583+0,480 \mathrm{X} 3$ \\
\hline $\mathrm{X} 31: \mathrm{X} 4=\mathrm{a}+\mathrm{bX} 1$ & $\mathrm{a}=68,261$ & $\mathrm{~b}=0,401$ & $\mathrm{X} 3=68,261+0,401 \mathrm{X} 1$ \\
\hline $\mathrm{X} 32: \mathrm{X} 4=\mathrm{a}+\mathrm{bX2}$ & $\mathrm{a}=42,088$ & $\mathrm{~b}=0,809$ & $\mathrm{X} 3=42,088+0,809 \mathrm{X} 2$ \\
\hline
\end{tabular}


Each form of regression equation is tested by linearity test and ANAVA significance test by using sum of squares $(\mathrm{JK})$ and average squares quantity (RJK). The hypothesis proposed in the data linearity test is as follows:

H0: regression model is not linear

H1: linear regression model

Testing criteria:

H0: received if Fhit $\geq$ Ftab

H0: rejected if Fhit $<$ Ftab, at $\alpha=0.05$

To test the significance of the proposed hypothesis as follows:

H0: regression model is not significant

H1: significant regression model

Testing criteria:

Ho: received if Fhit $\leq$ Ftab

H0: rejected if Fhit> Ftab, at $\alpha=0.05$

The summary of linearity test results and significance tests are as follows:

Table 3. Summary of Test Result Data of linearity and significance

\begin{tabular}{|l|c|c|c|c|c|c|c|}
\hline \multicolumn{2}{|c|}{ Variable data } & \multicolumn{3}{c|}{ Linearity Testing } & \multicolumn{3}{c|}{ Testing Significance } \\
\cline { 3 - 8 } & & $\begin{array}{c}\mathrm{F} \\
\text { count }\end{array}$ & $\begin{array}{c}\mathrm{F} \\
\text { table }\end{array}$ & $\begin{array}{c}\text { Results } \\
\text { Testing }\end{array}$ & $\begin{array}{c}\mathrm{F} \\
\text { count }\end{array}$ & $\begin{array}{c}\mathrm{F} \\
\text { table }\end{array}$ & $\begin{array}{c}\text { Results } \\
\text { Testing }\end{array}$ \\
\hline $\begin{array}{l}\text { Score performance } \\
\text { against self- } \\
\text { efficacy }\end{array}$ & $\mathrm{X} 4, \mathrm{X} 1$ & 1,31 & 1,88 & Linear & 14,89 & 3,97 & Significant \\
\hline $\begin{array}{l}\text { Performance score } \\
\text { on rewards }\end{array}$ & $\mathrm{X} 4, \mathrm{X} 2$ & 1,68 & 1,70 & Linear & 22,83 & 3,97 & Significant \\
\hline $\begin{array}{l}\text { Performance score } \\
\text { on work } \\
\text { motivation }\end{array}$ & $\mathrm{X} 4, \mathrm{X} 3$ & 0,92 & 1,88 & Linear & 19,85 & 3,97 & Significant \\
\hline $\begin{array}{l}\text { Work motivation } \\
\text { score on self- } \\
\text { efficacy }\end{array}$ & $\mathrm{X} 3, \mathrm{X} 1$ & 0,75 & 1,88 & Linear & 18,21 & 3,97 & Significant \\
\hline $\begin{array}{l}\text { Job motivation } \\
\text { score on rewards }\end{array}$ & $\mathrm{X} 3, \mathrm{X} 2$ & 1,62 & 1,70 & Linear & 22,07 & 3,97 & Significant \\
\hline
\end{tabular}

After tested by linearity test and regression significance test, then continued with significance test of correlation coefficient of exogenous variable with endogen variable through t-test, where $t$ hit $=r$ xy vn-1 $/ \sqrt{ }\left(1-r^{2}\right)$, while $t$ tab $(\alpha=0,05 ; d k=n-2)$ is known based on the distribution table t.

To test the significance of the correlation coefficient is proposed hypothesis:

H0: correlation coefficient is not significant

H1: significant correlation coefficient

Testing criteria:

H0: received if thit $\leq \mathrm{ttab}$

H0: rejected if thit $>\mathrm{ttab}$, at $\alpha=0.05 ; \mathrm{dk}=\mathrm{n}-2$

Summary of significance test correlation coefficient as follows: 
Table 4. Summary of significance test of simple correlation coefficient

\begin{tabular}{|c|c|c|c|c|c|c|}
\hline \multirow{2}{*}{$\begin{array}{l}\text { Relationship } \\
\text { variable }\end{array}$} & \multirow{2}{*}{$\begin{array}{l}\text { Notation } \\
\text { (rxy) }\end{array}$} & \multirow{2}{*}{$\begin{array}{l}\text { Correlation } \\
\text { coefficient }\end{array}$} & \multirow{2}{*}{$\stackrel{t}{\mathrm{t}}$} & \multicolumn{2}{|c|}{$\mathrm{t}$ tabel } & \multirow[t]{2}{*}{ Conclusion } \\
\hline & & & & $\begin{array}{c}\alpha= \\
0,05\end{array}$ & $\begin{array}{c}\alpha= \\
0,01\end{array}$ & \\
\hline $\begin{array}{l}\text { Self-Efficacy with } \\
\text { Performance }\end{array}$ & $\mathrm{r} 41$ & 0,195 & 2,055 & 1,992 & 2,642 & Significant \\
\hline $\begin{array}{l}\text { Performance } \\
\text { Rewards }\end{array}$ & $\mathrm{r} 42$ & 0,301 & 3,177 & 1,992 & 2,642 & Significant \\
\hline $\begin{array}{l}\text { Work Motivation } \\
\text { with Performance }\end{array}$ & r43 & 0,225 & 2,373 & 1,992 & 2,642 & Significant \\
\hline $\begin{array}{l}\text { Self-Efficacy with } \\
\text { Work Motivation }\end{array}$ & r31 & 0,307 & 3,207 & 1,992 & 2,642 & Significant \\
\hline $\begin{array}{l}\text { Rewards with Work } \\
\text { Motivation }\end{array}$ & r32 & 0,361 & 3,774 & 1,992 & 2,642 & Significant \\
\hline
\end{tabular}

\section{Research Results}

\section{MODEL TESTS, HYPOTHESES AND DISCUSSION}

The results of the research on self-efficacy variables (X1), rewards (X2), work motivation (X3) and performance (X4) which have been analyzed through descriptive statistics are presented in table 1 . The mean value of performance is 119.87 with 112 and median 120; standard deviation 17.10. Most performance scores were in the 111 - 119 interval class of 16 respondents. . Furthermore this ideal score can be classified into five categories as follows: score 84-98.2: very low, 98.2-112.4: low, 112.4-126.6: moderate, 126.6-140.8: high and 140.8155.0: very high. The result of comparison of mean empirical performance is 119, 87 with ideal mean value 119,5 and five category of performance quality, hence empirical mean score of performance variable is in medium category.

Table 5. Summary of Descriptive Statistical Analysis Results

\begin{tabular}{|l|c|c|c|c|}
\hline \multirow{2}{*}{ Analysis } & \multicolumn{4}{c|}{ Data variables } \\
\cline { 2 - 5 } & $\mathrm{X} 1$ & $\mathrm{X} 2$ & $\mathrm{X} 3$ & $\mathrm{X} 4$ \\
\hline B. Item & 33 & 25 & 31 & 32 \\
\hline B. Resp. & 79 & 79 & 79 & 79 \\
\hline Total Score & 9652 & 7308 & 9259 & 9470 \\
\hline Min & 84 & 73 & 84 & 84 \\
\hline Max & 158 & 111 & 151 & 155 \\
\hline Range & 74 & 38 & 67 & 71 \\
\hline Interval & 9,3 & 4,8 & 8,4 & 8,9 \\
\hline (fulfilled) & 10 & 5 & 9 & 9 \\
\hline B. Class & 7,26 & 7,26 & 7,26 & 7,26 \\
\hline (fulfilled) & 8 & 8 & 8 & 8 \\
\hline Mean & 122,18 & 92,51 & 117,20 & 119,87 \\
\hline S.dev & 17,60 & 9,56 & 16,12 & 17,10 \\
\hline Varians & 309,81 & 91,30 & 259,70 & 292,27 \\
\hline Median & 123 & 93 & 118 & 120 \\
\hline Modus & 116 & 92 & 120 & 112 \\
\hline
\end{tabular}

Thus it can be argued that the performance of heads of majors in Islamic universities in the city of Medan, the average is in the category of being. In more detail, the category of performance of department chairman of $11.4 \%$ is in very low category, $17.7 \%$ are in low category and $34.2 \%$ are in medium category, $25.3 \%$ are in high category, $11,4 \%$ are in category is very high. 


\section{Hypothesis testing}

Hypothesis testing is performed after first performing simple correlation analysis between variables as shown in table 6 below.

Table 6. Matrix of Correlations between Variables

\begin{tabular}{|c|c|c|c|c|}
\hline & $\mathrm{X} 4$ & $\mathrm{X} 1$ & $\mathrm{X} 2$ & $\mathrm{X} 3$ \\
\hline $\mathrm{X} 4$ & 1,000 & 0,402 & 0,478 & 0,453 \\
\hline $\mathrm{X} 1$ & 0,402 & 1,000 & 0,362 & 0,437 \\
\hline $\mathrm{X} 2$ & 0,478 & 0,362 & 1,000 & 0,472 \\
\hline $\mathrm{X} 3$ & 0,453 & 0,437 & 0,472 & 1,000 \\
\hline
\end{tabular}

Note:

$\mathrm{X}_{1}$ : Self-efficacy

$\mathrm{X}_{2}$ : Rewards

$\mathrm{X}_{3}$ : Work motivation

$\mathrm{X}_{4}$ : Performance

The summary of the exogenous variables path coefficient test results together with the endogenous variables through the F-test and the summary of the path coefficient test of each exogenous variable to the endogenous variable either directly presented in table 7 below:

Table 7. Summary of the results of coefficient test of exogenous variable paths together to endogenous variables through F-test

\begin{tabular}{|c|c|c|c|c|c|c|c|c|}
\hline \multirow[t]{3}{*}{ Variables } & \multirow{3}{*}{$\begin{array}{l}\text { Correlation } \\
\text { coefficient }\end{array}$} & \multirow{3}{*}{$\begin{array}{l}\text { Path } \\
\text { Coefficient }\end{array}$} & \multirow{3}{*}{$\begin{array}{l}\text { Coefficient of } \\
\text { Determinant }\end{array}$} & \multirow{3}{*}{$\begin{array}{l}\text { Residual } \\
\text { Coefficient }\end{array}$} & \multicolumn{4}{|c|}{ Hypothesis testing } \\
\hline & & & & & \multirow{2}{*}{$\begin{array}{c}\mathrm{F} \\
\text { count }\end{array}$} & \multicolumn{2}{|c|}{ F table } & \multirow[t]{2}{*}{ Conclusion } \\
\hline & & & & & & $\alpha=0,05$ & $\alpha=0,05$ & \\
\hline$\rho 31$ & 0,437 & 0,307 & \multirow[t]{2}{*}{0,3046} & \multirow[t]{2}{*}{0,8339} & \multirow[t]{2}{*}{16,65} & \multirow{5}{*}{2,74} & \multirow{5}{*}{4,06} & \multirow{5}{*}{$\begin{array}{l}\text { Reject Ho, then } \\
\text { H1 is received } \\
\text { with that } \rho 41 \text {, } \\
\rho 42, \rho 43 \text { is } \\
\text { significant or } \\
\text { significantly } \\
\text { different from } \\
\text { null, so it can be } \\
\text { passed through } \\
\text { individual tests } \\
\text { of each } \\
\text { exogenous } \\
\text { variable to the } \\
\text { endogenous } \\
\text { variable. }\end{array}$} \\
\hline$\rho 32$ & 0,472 & 0,361 & & & & & & \\
\hline$\rho 41$ & 0,402 & 0,195 & \multirow{3}{*}{0,3246} & \multirow{3}{*}{0,822} & \multirow{3}{*}{10,95} & & & \\
\hline$\rho 42$ & 0,478 & 0,301 & & & & & & \\
\hline$\rho 43$ & 0,453 & 0,225 & & & & & & \\
\hline
\end{tabular}


Table 8. Summary of hypothesis test of path coefficient of each exogenous variable to endogenous variable

\begin{tabular}{|c|c|c|c|c|c|c|}
\hline \multirow[t]{3}{*}{ Variables } & \multirow{3}{*}{$\begin{array}{l}\text { Correlation } \\
\text { coefficient }\end{array}$} & \multirow{3}{*}{$\begin{array}{l}\text { Path } \\
\text { Coefficient }\end{array}$} & \multicolumn{4}{|c|}{ Hypothesis testing } \\
\hline & & & \multirow[t]{2}{*}{$\begin{array}{c}\mathrm{t} \\
\text { count }\end{array}$} & \multicolumn{2}{|c|}{$\begin{array}{c}\mathrm{t} \\
\text { table }\end{array}$} & \multirow[t]{2}{*}{ Conclusion } \\
\hline & & & & $\begin{array}{r}\alpha= \\
0,05\end{array}$ & $\begin{array}{r}\alpha= \\
0,01\end{array}$ & \\
\hline$\rho 41$ & 0,402 & 0,195 & 2,056 & 1,992 & 2,642 & $\begin{array}{l}\text { Reject Ho, then the path of } \\
\text { direct positive influence has a } \\
\text { meaning. }\end{array}$ \\
\hline$\rho 42$ & 0,478 & 0,301 & 3,177 & 1,992 & 2,642 & $\begin{array}{l}\text { Reject Ho, then the path of } \\
\text { direct positive influence has a } \\
\text { meaning. }\end{array}$ \\
\hline$\rho 43$ & 0,453 & 0,225 & 2,373 & 1,992 & 2,642 & $\begin{array}{l}\text { Reject Ho, then the path of } \\
\text { direct positive influence has a } \\
\text { meaning. }\end{array}$ \\
\hline$\rho 31$ & 0,437 & 0,307 & 3,207 & 1,992 & 2,642 & $\begin{array}{l}\text { Reject Ho, then the path of } \\
\text { direct positive influence has a } \\
\text { meaning. }\end{array}$ \\
\hline$\rho 32$ & 0,472 & 0,361 & 3,774 & 1,992 & 2,642 & $\begin{array}{l}\text { Reject Ho, then the path of } \\
\text { direct positive influence has a } \\
\text { meaning. }\end{array}$ \\
\hline
\end{tabular}

Based on the calculation of path analysis on the structures 1 and 2 obtained the path coefficient values showing the causal relationship in the model structure that is analyzed as presented in the following figure:

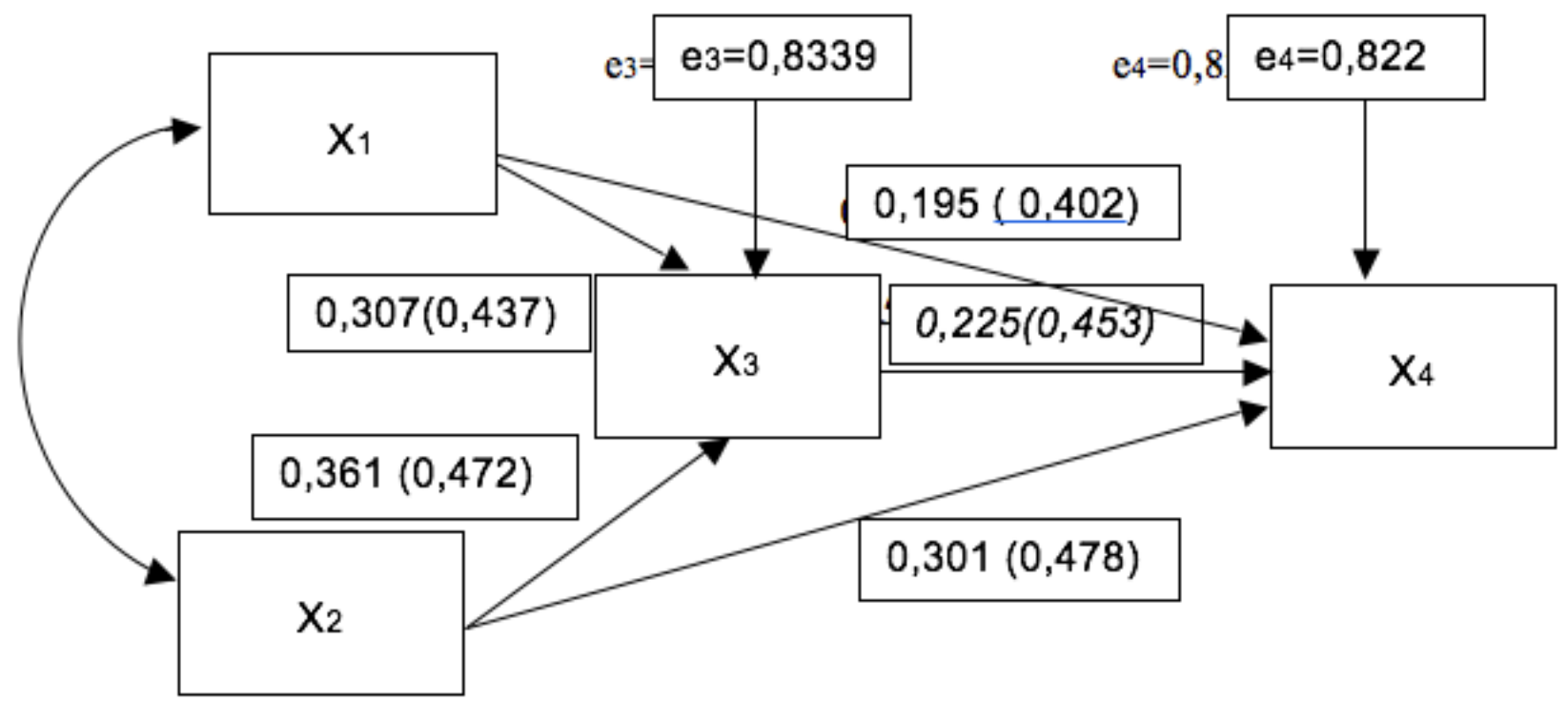

Figure 1. Model Calculation of path analysis and causal relationships within structure between self-efficacy variables, rewards, work motivation and performance.

\section{Hypothesis testing}

The first hypothesis: Self Efficacy (X1) has a direct positive effect on Performance (X4) Hypothesis tested:

Ho: $\rho 41 \leq 0$

H1: $\rho 41>0$ 
Based on calculation result obtained coefficient value of path $\rho 41=0,195$ with $t_{\text {hit }}=2,056$ and $t_{\text {tab }}=1,992$ at $\alpha=0,05$. Since $t_{\text {hit }}=2.056>t_{\text {tab }}(0,05,76)=1,992$, then Ho: $\rho 41 \leq 0$ is rejected, and H1: $\rho 41>0$ accepted that path coefficient $\rho 41=0,195$ is significant or significantly different with zero at significance level $\alpha=0,05$. By testing this hypothesis that self-efficacy has a direct positive effect on acceptable performance, it can be concluded that self-efficacy of head of study program of Islamic university in Medan have a direct positive effect to its performance.

Second Hypothesis: Reward (X2) has a direct positive effect on Performance (X4) Hypothesis tested:

Ho: $\rho 42 \leq 0$

H1: $\rho 42>0$

Based on the calculation result, the coefficient value of path $\rho 42=0,301$ with $t_{\text {hit }}=3,177$ and $t_{\text {tab }}=1,992$ at $\alpha=0,05$ and $t_{\text {tab }}=2,642$ at $\alpha=0,01$. Because $t_{\text {hit }}=3.177>t_{\text {tab }}(0,05,76)=1,992$ and $t_{\text {tab }}(0,01,76)=2,642$, then Ho: $\rho 42 \leq 0$ is rejected, and H1: $\rho 42>0$ accepted that path coefficient $\rho 42=0,301$ is significant or significantly different from zero at significance level $\alpha=$ 0,05 and $\alpha=0,01$. With this tested hypothesis that the rewards have a direct positive effect on acceptable performance, it can be concluded that the rewards of head of study program of Islamic universities in Medan have a direct positive effect on its performance.

Third Hypothesis: Work Motivation (X3) has a positive direct effect to Performance (X4) Hypothesis tested:

Ho: $\rho 43 \leq 0$

H1: $\rho 43>0$

Based on calculation result obtained coefficient value of path $\rho 43=0,225$ with thit $=2,373$ and $\operatorname{ttab}=1,992$ at $\alpha=0,05$. Because thit $=2,373>\operatorname{ttab}(0,05,76)=1,992$, then Ho: $\rho 43 \leq 0$ is rejected, and H1: $\rho 43>0$ accepted that path coefficient $\rho 43=0,225$ is significant or significantly different with zero at significant level $\alpha=0,05$ and $\alpha=0.01$. By testing this hypothesis that the work motivation has a direct positive effect on the acceptable performance, it can be concluded that the work motivation of the head of the Islamic Higher Education Program in Medan has a direct positive effect on its performance.

Fourth hypothesis: Self Efficacy (X1) has a positive direct effect on Work Motivation (X3) Hypothesis tested:

Ho: $\rho 31 \leq 0$

H1: $\rho 31>0$

Based on the calculation result, the coefficient value of path $\rho 31=0,307$ with $t_{\text {hit }}=3,207$ and $t_{\text {tab }}=1,992$ at $\alpha=0,05$ and $t_{\text {tab }}=2,642$ at $\alpha=0,01$. Because $t_{\text {hit }}=3.207>t_{\text {tab }}(0,05,76)=1,992 t_{\text {tab }}$ $(0,01,76)=2,642$ and, then Ho: $\rho 31=0$ rejected, and H1: $\rho 31>0$ accepted that path coefficient $\rho 31=0,307$ is significant or significantly different from zero at the significance level $\alpha=0.05$. By testing this hypothesis that self-efficacy has a direct positive effect on the work motivation is accepted, it can be concluded that the self-efficacy of head of study program of Islamic university in Medan have a direct positive effect on the motivation of its work.

The fifth hypothesis: The reward (X2) has a positive direct effect on Work Motivation (X3) Hypothesis tested:

Ho: $\rho 32 \leq 0$

H1: $\rho 32>0$ 
Based on calculation result obtained coefficient value of path $\rho 32=0,361$ with thit $=3,774$ and $\mathrm{ttab}=1,992$ at $\alpha=0,05$ and $\mathrm{ttab}=2,642$ at $\alpha=0,01$. Because thit $=3.774>\operatorname{ttab}(0,05,76)=$ 1,992 ttab $(0,01,76)=2,642$ and, then Ho: $\rho 32 \leq 0$ is rejected, and H1: $\rho 32>0$ accepted that path coefficient $\rho 32=0,361$ is significant or significantly different from zero at the significance level $\alpha=0.05$. With this tested hypothesis that the rewards have a direct positive effect on the work motivation is accepted, it can be concluded that the reward of head of study program of Islamic university in Medan have a direct positive effect on his work motivation. Based on the hypothesis testing data, then the results can be summarized in table 9 below.

Table 9. Summary of hypothesis testing results

\begin{tabular}{|c|c|c|c|c|c|}
\hline \multirow[t]{2}{*}{$\begin{array}{l}\text { Research } \\
\text { Hypothesis }\end{array}$} & \multirow[t]{2}{*}{ Statistic test } & \multirow[t]{2}{*}{$\begin{array}{c}\mathrm{t} \\
\text { count }\end{array}$} & \multicolumn{2}{|c|}{$\begin{array}{c}\mathrm{t} \\
\text { table }\end{array}$} & \multirow[t]{2}{*}{ Information } \\
\hline & & & $\begin{array}{r}A= \\
0,05\end{array}$ & $\begin{array}{r}\alpha= \\
0,01\end{array}$ & \\
\hline $\begin{array}{l}\text { Self-efficacy has a } \\
\text { direct positive } \\
\text { effect on } \\
\text { performance }\end{array}$ & $\begin{array}{l}\text { Ho: } \rho 41=0 \\
\text { H1: } \rho 1>0\end{array}$ & 2,056 & 1,992 & 2,642 & $\begin{array}{l}\text { Reject Ho, then the path of direct } \\
\text { positive influence has a meaning. }\end{array}$ \\
\hline $\begin{array}{l}\text { Rewards have a } \\
\text { positive direct } \\
\text { effect on } \\
\text { performance }\end{array}$ & $\begin{array}{l}\text { Ho: } \rho 42=0 \\
\text { H1: } \rho 42>0\end{array}$ & 3,177 & 1,992 & 2,642 & $\begin{array}{l}\text { Reject Ho, then the path of direct } \\
\text { positive influence has a meaning. }\end{array}$ \\
\hline $\begin{array}{l}\text { Work Motivation } \\
\text { has a direct } \\
\text { positive effect on } \\
\text { performance }\end{array}$ & $\begin{array}{l}\text { Ho: } \rho 43=0 \\
\text { H1: } \rho 43>0\end{array}$ & 2,373 & 1,992 & 2,642 & $\begin{array}{l}\text { Reject Ho, then the path of direct } \\
\text { positive influence has a meaning. }\end{array}$ \\
\hline $\begin{array}{l}\text { Self-efficacy has a } \\
\text { direct positive } \\
\text { effect on Work } \\
\text { Motivation }\end{array}$ & $\begin{array}{l}\text { Ho: } \rho 31=0 \\
\text { H1: } \rho 31>0\end{array}$ & 3,207 & 1,992 & 2,642 & $\begin{array}{l}\text { Reject Ho, then the path of direct } \\
\text { positive influence has a meaning. }\end{array}$ \\
\hline $\begin{array}{l}\text { Rewards have a } \\
\text { direct positive } \\
\text { effect on Work } \\
\text { Motivation }\end{array}$ & $\begin{array}{l}\text { Ho: } \rho 32=0 \\
\text { H1: } \rho 32>0\end{array}$ & 3,774 & 1,992 & 2,642 & $\begin{array}{l}\text { Reject Ho, then the path of direct } \\
\text { positive influence has a meaning. }\end{array}$ \\
\hline
\end{tabular}

\section{Direct and Indirect Influence among Variables}

The direct or indirect effect between variables is a form of influence based on path coefficient values. The effect occurs on endogenous variables caused by exogenous variables in certain structures, because there are times when an endogenous variable in a particular structure becomes an exogenous variable in the other structure. Test results on the direct and indirect effects of each variable on the other variables are presented in table 10 below:

Table 10. Summary of Direct and Indirect Influence variables

\begin{tabular}{|l|l|l|l|l|l|l|l|l|l|}
\hline \multicolumn{5}{|c|}{ Direct Effect } & \multicolumn{5}{|c|}{ Indirect Influence } \\
\hline & $\mathrm{X} 1$ & $\mathrm{X} 2$ & $\mathrm{X} 3$ & $\mathrm{X} 4$ & $\mathrm{X} 1$ & $\mathrm{X} 2$ & $\mathrm{X} 3-\mathrm{X} 4$ & $\mathrm{X} 1-\mathrm{X} 4$ & $\mathrm{X} 2-\mathrm{X} 4$ \\
\hline $\mathrm{X} 1$ & & & 0,1913 & 0,1620 & & & 0,0598 & & \\
\hline X2 & & & 0,2227 & 0,2287 & & & 0,1088 & & \\
\hline X3 & & & & 0,2050 & & & & & \\
\hline X4 & & & & & & & & & \\
\hline
\end{tabular}

Test results in the above table shows that the direct effect of X1 to X3 is 0.1913 , the direct effect of X1 to X4 of 0.1620 , the direct effect of X2 to X3 of 0.2227, the direct influence of X2 to 
$\mathrm{X} 4$ of 0.2287 and the influence direct $\mathrm{X} 3$ to $\mathrm{X} 4$ is equal to 0.2050 . While indirect influence between X1 to X4 through X3 is equal to 0,0598, indirect influence X2 to X4 through X3 equal to 0,1088 ,

Based on the results of this test can be stated that the effect of self-efficacy of head of study program at Islamic university in Medan directly to work motivation is $19,13 \%$ while selfefficacy influence to performance equal to $16,20 \%$. The direct effect of reward to work motivation is $22.27 \%$, the direct effect of return on performance is $22.87 \%$. The direct influence of work motivation on performance is $20.50 \%$. From this data can be argued that the greatest influence on performance is the reward of $22.87 \%$, while the smallest influence on performance is self-efficacy that is equal to $16.20 \%$.

\section{DISCUSSION}

The results of this study indicate that the performance model tested in this study is acceptable. Thus a performance model can be built through work motivation variables, self-efficacy and rewards. From the test results found that the biggest variables affecting performance is the variable reward while the next variable is the motivation of work and the lowest influence is self-efficacy. Rewards affect performance by $22 \%$, while motivation $20 \%$ and self-efficacy $16 \%$. . The results of this test means that if you want to improve the quality of the performance of the department chairman in PT Islam in Medan City, it is necessary to improve the quality of individual assessment of the rewards received considering this reward gives $22 \%$ influence on work motivation and work motivation gives $20 \%$, as well as self-efficacy affect the motivation of work about $19 \%$.

The acceptance of performance model test results built through this research reinforces Kinicki's (2006) developed performance model, where variables sourced from individual input and job context and motivation variables can be used to build a performance model. Similarly, Robin's concept of performance that says that performance is the behavior and traits in work are tested in this study.

If analyzed more deeply in the performance of the head of study program at Islamic Higher Education in Medan city, it can be argued that their performance is generally in enough categories. Based on the results of this study it can be argued that the appearance of the chairman of the study program in conducting interpersonal relationships is quite good, as well as their behavior in identifying and solving problems in a way that is acceptable to members quite well. Then the behavior of the Program Study leaders in adjusting the leadership style to the different situations and their behavior in setting the study objectives is also quite good. Nevertheless, among the leaders of this study program, generally there are those who have achieved very good performance that is around $11 \%$ and $25 \%$ good and $34 \%$ enough. Among them there are also $17 \%$ still having problems with their performance.

The result of research on work motivation of the head of study program at Islamic University in Medan City also shows the condition which is not much different from the state of its performance. Generally their work motivation is in enough categories. If in this study motivation is defined as the strength of individuals in completing tasks and responsibilities, then their strength in determining the direction and behavior is quite good, as well as their level of effort and endurance is quite good. Nevertheless there are still among those who have excellent work motivation of about $11 \%$, both $21 \%$ and quite good $34 \%$, while those with poor motivation of $12 \%$. 
Based on the results of this analysis on motivation and performance can be stated that if the motivation of work is in sufficient category then the performance is also in the category enough. This situation seems to be in line with the state of other variables. The rewards and self-efficacy of the head of study program at Islamic Higher Education in Medan City are in enough categories. Assessment of the chairperson of the study program on rewards sourced from such institutions as income, promotion, opportunities to improve skills and health services are in sufficient category. Similarly, their madness regarding rewards sourced from psychological rewards such as a feeling of joy for success in completing a task, a sense of meaning for others and satisfaction with work performance is also in the category of sufficient.

The result of self-efficacy analysis which gives the smallest effect to the performance shows that the condition in the head of study program in Islamic university in Medan city is also sufficient. This means their belief in their ability to complete the task, the belief in the ability to overcome obstacles and the belief in endurance when finding failure is in enough categories. Thus it can be concluded that the performance of the chairman of the study program in Islamic High School in Medan which is currently in the category is quite sourced from the state of motivation, rewards and self-efficacy are still relatively in the category enough. However, other factors not tested in this study also affect the performance.

This study has also examined the indirect relationship between variable rewards to performance. Through work motivation, rewards have an influence of about $10 \%$ on performance. The results of this study indicate that the direct effect of direct reward to performance is about $16 \%$ compared with its influence through work motivation, while the direct effect of reward to work motivation is about 19\%. This situation can be interpreted that the individual's valuation of the reward earned is actually more powerful to influence work motivation than with performance. It can be understood that the performance of a person is derived from the quality of motivation it has while the reward is its function to strengthen the motivation of work in achieving performance. If the results of this analysis are compared with other performance models such as those proposed by Griffin, Gibson, Robin indicating on the performance model that effort directly affect the Kidney, it can be stated that this effort is actually a driver to achieve performance, in other words in motivation work there are certain efforts to achieve performance. Thus from several analysis results to some variables used in the performance model was in the discussion of motivation and effort visible similarity of meaning even though the terminology used is different.

A deeper analysis of the efficacy of self to performance shows that its direct effect on performance is greater (16\%) than its influence through motivation (5\%). This means that self-efficacy is the individual's confidence to be able to complete his work much more influence on his performance than with its influence on work motivation. This situation indicates that self-efficacy is actually more describes the individual picture of the strength it has to work, so that self-efficacy is more directed to performance. When associated with the opinion of Colquit who argued that performance is an individual behavior based on a certain value in contributing to the achievement of organizational goals, where performance has three dimensions called task performance, citizenship behavior and counterproductive behavior, then variable rewards included in task performance, work motivation belongs to citizenship behavior and self-efficacy included in counterproductive behavior.

Task performance is the performance of tasks that directly affect the transformation of the source of the organization into potential or service generated. Rewards as expected by individuals are acceptable in accordance with the desired task, in which a person will exert his or her potential in providing services within the organization expecting to be rewarded as 
expected when the work has been completed. Citizenship behavior is the willingness of individuals to do something to the organization either rewarded or not. Work motivation is a series of forces from within and outside that cause the worker to choose the way to perform actions against a particular behavior. Work motivation included in the citizenship behavior where through the motivation of work someone will be willing to do something to the organization either rewarded or not. In other words work motivation is a force that causes a person willing to do something against the organization either rewarded or not so as to improve performance in achieving goals. Furthermore, counterproductive behavior is a behavior that is shown by individuals that can hinder the achievement of organizational goals. Self-efficacy is a person's belief in his ability to accomplish a particular task. Someone who does not have high self-efficacy, then counterproductive behavior dimension in performance will emerge, so that can hamper performance improvement, whereas if on the contrary, someone who has high self-efficacy, counterproductive behavior dimension in performance will not appear. Based on empirical findings through variable rewards, work motivation and self-efficacy, these three dimensions of performance have been tested to determine in performance improvement.

If the results of this study are related to Path Goal Theory proposed by Locke and Latham, then it appears that the real desire to achieve that goal is actually a part of the motivation of work, so the effect of self-efficacy on work motivation is lower than the effect on performance. According to this theory the achievement of objectives and efficacy are true that encourage individuals to achieve performance. So in another explanation Lock and Latham suggest that there is a combined effect of self-efficacy, the target set by a person in achieving his goals with his performance. Thus the more clearly understood that the effect of self-efficacy on performance through work motivation is actually influenced by the target achievement goals that are part of the work motivation. Therefore, influence of efficacy against work motivation greater on the indicator level of business and endurance while the effect of rewards to motivation more work great towards the determination of direction and behavior. The results of this analysis can answer the difference in the effect of self-efficacy on performance through work motivation with the effect of rewards on performance through work motivation.

Based on the results of the research analysis of the performance models built through selfefficacy variables, rewards and work motivation can be argued that this model is tested as a performance model. Then this model is also tested to give explanation about the performance phenomenon of head of study program of Islamic Higher Education in Medan City. Besides this model can also explain the circumstances of the chairman of the study program, so it can be predicted some things that are possible to develop the performance of the department leader, especially the improvement of performance through self-efficacy variables, rewards and work motivation.

\section{CONCLUSION}

This study found that the quality management of higher education had a correlation with the job satisfaction of human resources in which same influential factors; self-efficacy, rewards and motivation involved. The research model proposed with self-efficacy influence variables, rewards, and work motivation can be accepted as a model of performance development of the head of the study program of Islamic Higher Education in Medan. Those have a positive direct effect on performance. The work motivation had a directly positive effect on performance. Thus, the work motivation on the performance of the head of the study program of Islamic Higher Education in Medan significantly effect. Self-efficacy has a positive direct effect on work motivation. A direct positive effect of self-efficacy on work motivation of head of study program of Islamic university in Medan was proven. Growing self-confidence for the Program 
Study chairman was giving confidence to the chairman of the study program in carrying out the program study tasks. With the success of the chairman of the study program through this stage, it is expected that his efficacy will increase, so the next will be able to improve performance. It found that the performance was improved due to the adjustment of the rewards earned by individuals.

\section{BIBILIOGRAPHY}

Ajmal, A., Mohsin B., Abrar, M., Khan, M.M, Saqib, S. 2015. The Effects of Intrinsic and Extrinsic Rewards on Employee Attitudes; Mediating Role of Perceived Organizational Support. Journal of Service Science and Management, 8, 461-470

Abdulwahab S. 2016. The relationship between job satisfaction, job performance and employee engagement: An explorative study. Issues in Business Management and Economics. 4(1): 1-8, DOI: http://dx.doi.org/10.15739/IBME.16.001

Bergström, E. \& Melanie, G.M. 2016. Umeå School of Business and Economics Spring semester 2016 Degree project, $30 \mathrm{hp}$.

Colquit, 2009. Organizational Behavior. New York: Mc Graw Hill, 2009.

Crespo, B. et al. 2017. The Sustainable Development Goals: An Experience on Higher Education. Sustainability 2017, 9, 1353; doi:10.3390/su9081353

Dehaghi, M.R, Abbas, R. 2014. Studying the Relationship between the Effective Factors on Employees'

Performance in Iran's University and the Students' Satisfaction with regards to Employees' Performance. Procedia - Social and Behavioral Sciences 141 (2014) 903 - 908.

Ferrer-Balas, J. Adachi, S. Banas, C.I. Davidson, A. Hoshikoshi, A. Mishra, Y. Motodoa, M. Onga, M. Ostwald.2008."An international comparative analysis of sustainability transformation across seven universities", International Journal of Sustainability in Higher Education 9 (3):295 - 316

Foster, C., Breckons, M., Cotterell, P., Barbosa, D., Calman, L., Corner, J., ... \& Smith, P. W. 2015. Cancer survivors' self-efficacy to self-manage in the year following primary treatment. Journal of Cancer Survivorship, 9(1), 11-19.

Greenberg, J., \& Baron, R. A. (2008) Motivation in Organition. New Jersey.

Inuwa, M. 2016. Job Satisfaction and Employee Performance: An Empirical Approach. The Millennium University Journal; 1(1); 2016.90-103

Jennifer M.George \& Gareth R.Joner. 2009. Understanding and Managing Organizational Behavior. Prentice Hall.

Kapinga, O. \& Jaqueline A. 2016. Determinants of Students' Academic Performance in Higher Learning Institutions in Tanzania. Journal of Education and Human Development 5(4): 78-86. DOI: 10.15640/jehd.v5n4a8

Khan, R.A. et al. 2011. Impact of Training and Development on Organizational Performance. Global Journal of Management and Business Research 11 (7), 1-7

Kinicki, A. \& Robert, K. 2006. Organizational Behavior. Mc Graw-Hill International Edition,

Koopmans, L. et al. 2011. Conceptual Frameworks of Individual Work Performance: A Systematic Review. JOEM _ 53(8),856-866

Lunenburg, F.C.2011. Goal-Setting Theory of Motivation. International Journal Of Management, Business, And Administration 15(1): 1-6

Mensah, E. \& Kwesi, A. 2016. Employee Motivation and Work Performance: A Comparative Study of Mining Companies in Ghana. Journal of Industrial Engineering and Management 9(2): 255-309http://dx.doi.org/10.3926/jiem.1530

Muda, I., Ahmad, R., \& Harahap, M.R. 2014. Factors Influencing Employees' Performance: A Study on the Islamic Banks in Indonesia. International Journal of Business and Social Science 5(2); 1-8

Nurun Nabi, Monirul, I., \& Tanvir, M., \& Abdullah, A.. 2017. Impact of Motivation on Employee Performances: A Case Study of Karmasangsthan Bank Limited, Bangladesh. Arabian Journal of Business and Management Review. 7(1): $1-8$.

Sharma, R. , \& Singh, S. 2017. Transformational Leadership Style and Self-Efficacy among Teaching Professionals. The International Journal of Indian Psychology 4(2) DIP: 18.01.036/20170402 
Sinawi, S, Chua, Y.P. , Idris, A.R. 2015. Factors Influencing the Employees' Service Performance in Ministry of Education in Sultanate of Oman. Procedia - Social and Behavioral Sciences 197 ( 2015 ) 23 - 30.

Slocum, H. 2009. Principles of Organizational Behavior. South-Western-Cengage Learning.

Taylor, J. 2016. Competency-based Education Brief. University of Colorado. Office of Academic Affairs 1800 Grant Street,

Teo, T.C. \& Low, K.C. 2016. The Impact of Goal Setting on Employee Effectiveness to Improve Organisation Effectiveness: Empirical study of a High-Tech Company in Singapore. Journal of Business \& Economic Policy 3(1); 82-97.

Türk, K. 2016. Performance Management Of Academic Staff And Its Effectiveness To Teaching And Research Based On The Example Of Estonian Universities. Trames, 2016, 20 (70/65), 1, 17-36

Türkoğlu, M.E, Ramazan C., Hanifi, P. 2017. Examining Relationship between Teachers' Self-efficacy and Job Satisfaction. Universal Journal of Educational Research 5(5): 765-772, DOI: 10.13189/ujer.2017.050509

Vosloban, R.I. 2012. The Influence of the Employee's Performance on the company's growth - a managerial perspective. Procedia Economics and Finance 3 ( 2012 ) 660 - 665.

Yadak, S.M.A. 2017. The Impact of the Perceived Self-Efficacy on the Academic Adjustment among Qassim University Undergraduates. Open Journal of Social Sciences, 5, 157-174.

http://dx.doi.org/10.4236/jss.2017.51012 